\title{
PEMBERDAYAAN PEREMPUAN MELALUI KREDIT MIKRO POLA GRAMMEN BANK (Studi Kasus Anggota Koperasi Syariah Benteng Mikro Indonesia Cabang Lebak Banten)
}

Musahwi* $^{*}$

IAIN Syekh Nurjati

Pitriyani $^{2}$

Universitas Sultan Ageng Tirtayasa email: awiemuss@gmail.com

email: yanipitri56@gmail.com

•Received: 29 April 2021 •Accepted: 3 Mei 2021 •Published online: 1 Juni 2021

\begin{abstract}
Abstrak:
Penelitian ini bertujuan untuk mendeskripsikan tentang pemberdayaan perempuan melalui program kredit mikro Koperasi Syariah Benteng Mikro Indonesia yang menggunakan pola Grammen Bank. Penelitian ini menggunakan metode kualitatif deskriptif dengan wawancara mendalam dan observasi langsung. Hasil penelitian menunjukan bentuk pemberdayaan yang diberikan oleh Koperasi Syariah Benteng Mikro Indonesia berupa pemberian kredit mikro tanpa aguman khusus untuk perempuan, pelatihan mengelola keuangan keluarga melalui simpanan wajib dan sukarela, kegiatan perkumpulan melalui Rembug Pusat.
\end{abstract}

Kata Kunci: Pemberdayaan Perempuan, Kredit Mikro, Grammen Bank

\section{Abstract:}

This research aims to describe about the empowerment of women through the Koperasi Syraiah Benteng Mikro Indonesia micro credit program that uses the Grammen Bank pattern. Using a qualitative descriptive method with in-depth interviews and direct observation. The results of the research show that the form of empowerment provided by Koperasi Syariah Benteng Mikro Indonesia is in the form of providing micro credi without guarantee for women, trainig in family financial management through compulsory and voluntary savings, association activities through central consultation (Rembug Pusat).

Keyword: Women Empowerment, Micro Credit, Grammen Bank

\section{A. PENDAhuluan}

Isu tentang kesetaraan gender hingga saat ini masih menjadi polemik dimasyarakat. Kesetaraan yang diharapkan kaum perempuan selalu menjadi sesuatu yang mahal dan sulit didapatkan. Pandangan perempuan sebagai 'The Second Sex' atau 'warga kelas dua' yang keberadaannya tidaklah begitu diperhitungkan didalam masyarakat. Di Indonesia

\footnotetext{
${ }^{*}$ Corresponding Author, Email: awiemuss@gmail.com
} 
Musahwi, Pitriyani

sendiri perempuan selalu dikaitkan dengan kata "sumur, dapur, dan kasur". Adanya pelabelan tugas perempuan dari tiga hal tersebut menunjukan bahwa pekerjaan mereka didominasi oleh pekerjaan domestik (homemaker) yang dinilai tidak dapat berkontribusi secara aktif diluar rumah sehingga tugas seoarang perempuan hanya sekedar aktivitas dalam rumah.

Menurut Iwan (2013) menyebutkan bahwa pekerjaan domestik tidak pernah dianggap sebagai sebuah pekerjaan. Hal ini dikarenakan pekerjaan domestik tidak menghasilkan uang dalam aspek ekonomi sehingga pekerjaan perempuan tersebut bukan bagian pekerjaan yang produktif. Pandangan ini telah hidup didalam masyarakat dan menjadi budaya. Misalnya pada dunia pekerjaan, tertutupnya akses bagi perempuan untuk memiliki posisi yang strategis karena dianggap tidak pantas pemimpin pekerjaan. Perempuan dianggap sebagai makhluk yang emosional dan sulit mengambil keputusan dengan bijak.

Di dalam lingkup keluarga seringkali seorang istri memiliki peran yang lebih sedkit ketimbang suami dalam hal pengambilan keputusan keluarganya. Dalam masalah ekonomi keluarga perempuan hanya berperan sebagai ibu rumah tangga yang bergantung pada pendapatan suami, sehingga memunculkan anggapan bahwa perempuan sebagai penerima pasif pembanguunan (Abdullah, 2001:104). Konstruksi sosial yang melekatkan kaum perempuan pada sifat - sifat feminim dan pekerjaan yang memberikan tenaga dan perhatiannya demi kepentingan keluarga tanpa boleh mengharapkan imbalan, prestise dan kekuasaan telah menjadi bentuk marginalisasi perempuan didalam keluarga.

Masalah ketimpangan gender tersebut perlu adanya pemahaman yang berbeda mengenai posisi dan peran perempuan didalam keluarga maupun masyarakat. Pemberdayaan perempuan dalam bidang ekonmi dapat menjadi salah satu upaya membongkar masalah tersebut. Rahayu (2015) menyebutkan bahwa indikator meningkatnya kesejahteraan ekonomi keluarga dilihat pada keterlibatan perempuan dalam mengambil keputusan. Kemudian Hartiningsih (2013) juga memaparkan bahwa perempuan harus diberikan akses terhadap informasi dan kebebasan berpendapat mengenai haknya dalam kehidupan ekonomi, sosial dan politik dilingkungan mereka. Peran pemberdayaan perempuan sangat dibutuhkan dalam mewujudkan kondisi tersebut. Pemberdayaan yang dimaksud dapat dimulai dengan kesetraan posisi perempuan dalam keluarga dimulai dengan keterlibatakan mereka dalam pengambilan 
Musahwi, Pitriyani

keputusan, keterbukaan akses memperoleh sumber daya produkti sampai keaktifan pada aspek publik seperti perkumpulan.

Program kredit mikro merupakan salah satu pemberdayaan masyarakat yang dapat dimanfaatkan perempuan untuk keluar dari lingkaran marginalisasi diskriminasi budaya patriarki. Melalui program ini perempuan dapat mengekspolarasi kemampuan dan potensinya dengan lebih baik. Akses pemberian modal usaha yang diperoleh kaum perempuan dapat menjadi awal pemberdayaan perempuan khususnya pada keluarga pra sejahtera. Menurut Bagum dalam (Rachamina, 2009:13) mengungkapkan istilah "to our credit" yaitu contoh nyata dari kondisi orang - orang (miskin) yang lebih mudah mencapai potensi dirinya sepenuhnya setelah diberikan akses kredit. Ia pun menambahkan bahwa akses kredit yang diberikan bukannya untuk memberantas masalah kemiskinan semata namun juga sebagai "kesadaran sosial" terhadap potensi yang ada pada masyarakat itu sendiri.

Koperasi Syariah Benteng Mikro Indonesia atau disingkat dengan Kopsyah BMI merupakan satu dari sekian lembaga yang menyadari pentingnya pemberdayaan perempuan pada keluarga pra sejahtera. Melalui produk simpan pinjam tanpa agunan, koperasi ini memiliki tujuan untuk mengembangkan potensi kredit mikro di pedesaan dengan memberikan akses pedanaan usaha skala mikro, memperkuat solidaritas kaum perempuan, mengelola zakat, infaq/sedekah, wakaf. dan mendorong pengangguran keluarga pra sejahtera agar lebih produktif. Dengan memodifikasi pola Grammen Bank, Kopsyah BMI berfokus pada pemberdayaan masyarakat keluarga pra sejahtera dan kaum perempuan.

Koperasi yang didirikan oleh Badan Perencanaan dan Pembangunan Daerah (BAPPEDA) Kabupaten Tangerang dan Lembaga Sumberdaya Informasi Institut Pertanian Bogor (LSI-IPB) ini memliki lima instrumen pemberdayaan yang t terdiri dari Sedekah, pinjaman, pembiayaan, tabungan atau simpanan dan investasi. Kelima instrumen tersebut berbasis pada nilai dan norma syariah yang menjadi pedoman utamanya terutama dalam memberdayakan kaum perempuan dan anak - anak.

\section{B. METODOLOGI PENELITIAN}

Penelitian ini dilakukan di Desa Girimukti Kecamatan Cimarga Kabupaten Lebak Banten yang merupakan salah satu wilayah anggota Koperasi Syariah Benteng Mikro Indonesia cabang 32 Kalanganyar. 
Musahwi, Pitriyani

Dasar penelitian yang digunakan dalam penelitian ini adalah metode kualitatif, dengan tipe penelitian deskriptif. Menurut Satori dan Komariah (2013:25) penelitian kualitatif deskriptif merupakan pendekatan dalam mengungkap situasi sosial tertentu secara kenyataan dilapangan dalam bentuk kata - kata berdasarkan teknik pengumpulan dan analisis data relevan yang diperoleh dari situasi yang alamiah.

Data penelitian diperoleh dari hasil wawancara mendalam dengan informan dan observasi langsung. Informan yang menjadi sumber data primer penelitian ini terdiri dari tiga perempuan anggota kredit mikro Koperasi Syariah Benteng Mikro Indonesia seperti pada Tabel 1.

Tabel 1. Informan Penelitian

\begin{tabular}{|l|l|}
\hline \multicolumn{1}{|c|}{ Informan } & \multicolumn{1}{c|}{ Keterangan } \\
\hline Ibu Emun & Pedagang Nasi Uduk \\
\hline Ibu Ajah & Pedagang Pecel \\
\hline Ibu Acih & Pedagang Warung Kopi \\
\hline
\end{tabular}

\section{RESULT AND DISCUSSION}

Penelitian ini berangkat dari masalah kemiskinan keluarga pra sejahtera dan peran perempuan dalam membantu memberdayakan ekonomi keluarga. Pada penelitian ini akan dibahas mengenai dua hal yaitu sistem Koperasi Syariah Benteng Mikro Indonesia dalam persepektif konsep Grammen Bank dari Muhammad Yunus dan yang kedua pembahasan mengenai pemberdayaan perempuan yang diberikan oleh koperasi tersebut.

\section{Kredit Mikro Koperasi Syariah Benteng MI Melalui Pola Grammen Bank}

Koperasi Syariah Benteng Mikro Indonesia atau terkenal dengan nama Kopsyah BMI ini merupakan lembaga pembiayaan pengembangan usaha mikro kecil yang memberikan palayanan simpan pinjaman tanpa agunan dalam membatu meningkatkan perekonomian masyarakat menengah ke bawah untuk mewujudkan kesetraaan ekonomi. Lembaga ini awalnya merupakan hasil studi identifikasi skim-skim pembiayaan bagi pelaku UMKM yang dilakukan oleh Badan Perencanaan dan Pembangunan Daerah (BAPPEDA) Kabupaten Tangerang dan Lembaga Sumberdaya Informasi Institut Pertanian Bogor (LSIIPB) pada tahun 2002. Kemudian sejak tahun 2013 hingga sekarang lembaga ini berubah Badan Hukum menjadi KOPERASI SYARIAH BENTENG MIKRO INDONESIA (Apriliani, 2020:48). 
Musahwi, Pitriyani

Berdasarkan sejarahnya, lembaga ini merupakan terapan dari modifikasi pola Grammen Bank yang didirikan oleh Prof. Dr. Muhammad Yunus yang berasal dari Bangladesh. Sistem operasional yang digunakan koperasi tersebut adalah dengan membuat kelompok kecil di setiap daerah anggotanya yang disebut dengan Model Rembug Pusat. Fungsi dari Rembug Pusat tersebut adalah sebagai tempat berkumpulnya anggota koperasi dalam melakukan transaksi peminjaman ataupun simpanan. Selain itu, sasaran dalam pemberian pembiayaan koperasi ini juga memfokuskan pada keluarga pra sejahtera dan kaum perempuan. Prinsip tersebut hampir sama dengan sistem yang dipakai oleh Grammen Bank yaitu menggunakan sistem 'kelompok solidaritas' . Dan kaum perempuan yang menjadi target utama pada program koperasi terinspirasi dari pengalaman Muhammad Yunus dalam memberatas masalah kemiskinan di Bangladesh lewat pemberdayaan perempuan.

Dalam bukunya Muhammad Yunus (2007), ia menceritakan keperihatinannya kepada perempuan muncul ketika ia mendapati seorang perempuan desa yang terjerat hutang kepada seorang rentenir dengan syarat yang merugikan si perempuan tersebut. Menurut Yunus hal itu adalah cara membeli budak berlian dengan menguntungkan diri sendiri (Yusuf, 2008: 63-64). Sejak saat itu, Yunus mulai melakukan riset tentang kondisi perempuan pedesaan dalam memperoleh hak ekonominya. Setelah melakukan riset dengan beberapa mahasiswanya Yunus menemukan fakta bahwa kaum perempuan yang menjadi buruh harian dihargai upah yang termurah. Kemudian jika kaum perempuan dalam kondisi melarat dan tidak memiliki pekerjaan maka yang akan dilakukan adalah mengemis. Yunus pun melihat bahwa kaum perempuan yang menjadi buruh harian tersebut banyak yang menjadi seorang janda karena suaminya meninggal, cerai atau suaminya meninggalkannya pergi dengan anak - anak yang harus diberinya makan (Yusuf, 2008:65).

Kisah dan perjuangan Muhammad Yunus di atas telah memberikan inspirasi bagi banyak negara lainnya khususnya negara berkembang seperti Indonesia. Keberhasilan Grammen Bank membangkitkan lembaga - lembaga kredit mikro di Indonesia untuk mengikuti sistem bank tersebut dalam rangka membedayakan perkonomian keluarga pra sejahtera melalui pemberdayaan perempuan. Salah satu yang menerapkan sistem ini adalah Koperasi Syrariah Benteng Mikro Indonesia.

Terinspirasi dari sistem Grammen Bank Kopsyah BMI memiliki produk pelayanan dan sistem penyaluran yang sama yaitu pinjaman tanpa agunan dan simpanan anggota. Pinjaman tanpa aguman difokuskan bagi para pedagang dan anggota yang mempunyai 
Musahwi, Pitriyani

kesediaan menabung dan menghadiri perkumpulan di Rembug Pusat yang dilakukan secara rutin disetiap minggunya. Sedangkan untuk pelayanan program simpanan anggota dapat diperoleh semua anggota. Simpanan tersebut bertujuan untuk membantu masyarakat mengatasi kebutuhan darurat dan dana cadangan untuk memenuhi kewajiban pelunasan pinjaman yang diberikan. Tidak hanya simpanan wajib, adapula simpanan sukarela sebagai dana cadangan dimasa yang akan datang dan juga sebagai pemupukan modal (capital formation) dalam rangka peningkatan kemandirian anggota dan koperasi. Simpanan sukarela ini terdiri dari simpanan hari tua, pendidikan, Umroh dan Haji, Qurban, sanitasi dan air, sampai dengan simpanan untuk tamasya. Pada sistem Grammen Bank, Muhammad Yunus memang mendorong nasabahnya untuk menabung. Tabungan tersebut bertujuan untuk menjadi pegangan nasabah pada waktu susah atau dapat digunakan untuk menambah peluang - peluang meningkatkan pendapatan (Yusuf, 2008:66).

Pada pelayanan pinjaman tanpa agunan menjadi produk pelayanan utama dengan tujuan membantu masyarakat dalam memenuhi kebutuhan sehari - hari dan permodalan usaha dengan ketentuan yang mudah, cepat dan berada di ruang lingkup yang dekat dengan rumah anggota melalui Rembug Pusat (center meeting). Keaktifan kehadiran anggota pada kegiatan di Rembug Pusat menjadi agunan bagi koperasi. Pemberian besaran pinjaman menyesuaikan dengan kemampuan anggota untuk mengembalikannya (capacity to repay). Hal ini dilakukan agar tidak menyengsarakan anggota dikemudian hari karena terbebani oleh pinjamannya. Untuk pinjaman pertama dana yang diberikan maksimal 80\% dari nilai simpanan modal kerja. Lalu pinjaman kedua diberikan maksimal 90\%. Kemudian, pinjaman ketiga dan seterusnya diberikan 100\% dari dana yang dipinjamkan. Hal ini dilakukan agar angggota tidak bermasalah dikemudian hari dalam pelunasan pinjamannya. Sisa pinjaman pertama sebebar $20 \%$ sebagai simpanan wajib anggota yang dapat menjadi jaminan keterlambatan membayar angsuran. Selain itu, koperasi juga mewajibkan anggotanya menabung, pada minggu pertama peminjaman anggota wajib menabung sebesar 4\% dan minggu seterusnya sebesar 0,2\% dari dana yang dipinjamkan. Misalnya anggota meneriman pinjaman sebesar Rp. 3.000.000; maka simpanan wajib pertamanya adalah sebesar Rp. 130.000; dan minggu setelahnya atau seterusnya sebesar Rp. 6000; per minggu. Simpanan wajib tersebut dapat menutupi angsuran pelunasan yang tidak terbayar oleh anggota. Namun jika simpanan itu tidak digunakan menutupi angsuran pinjaman tersebut dapat diambil oleh anggota setelah 
Musahwi, Pitriyani

pinjaman lunas. Sistem simpanan wajib ini sedikit berbeda dengan sistem Grammen Bank yaitu simpanan wajib yang harus dibayarkan lebih besar yaitu sebesar 5\%.

Pengajuan pinjaman tanpa agunan yang ditawarkan Kopsyah BMI memiliki beberapa tahapan dan syarat yang harus dipatuhi oleh anggota. Adapun prosedur pengajuannya adalah sebagai berikut (Apriliani, 2020: 57):

1) Masyarakat melakukan pendaftaran sebagai anggota koperasi

2) Mengikuti kegiatan rutin kumpulan dalam Rembug Pusat setiap minggunya

3) Mengisi formulis pengajuan pinjaman dengan menyertakan potokopi KTP dan KK sebagai pelengkap identitas anggota

4) Menabung rutin setiap minggunya

5) Pencairan dilakukan diminggu berikutnya yang disaksikan oleh seluruh anggota yang hadir dalam perkumpulan Rembug Pusat

6) Pengucapan ikrar dan do'a, dan

7) Melakukan pembayaran pelunasan setiap minggunya sesuai dana yang diberikan

\section{Pemberdayaan Perempuan melalui Kredit Mikro Koperasi Syariah Benteng MI}

Kata 'pemberdayaan' berasak dari kata 'daya' yang artinya kemampuan atau tindakan untuk melakukan sesuatu. Sedangkan arti dari pemberdayaan perempuan adalah upaya atau kemampuan perempuan untuk melakukan susuatu yang menjadi haknya. Menurut Anonymous pemberdayaan Perempuan pada dasarnya merupakan suatu usaha perempuan keluar dalam kondisi ketidakadilan karena tidak memperolehnya akses dan kontrol terhadap sumber daya seperti ekonoi, politik, sosial dan budaya (Putri dkk, 2013 :147). Masalah ketimpangan ini disebabkan oleh budaya patriaki, yaitu nilai hidup masyarakat yang memposisikan laki - laki sebagai superior dan perempuan subordinat. Pemberdayaan terhadap perempuan bertujuan agar perempuan dapat meningkatkan rasa percaya diri, berperan dan berpartisipasi aktif guna mampu membangun dirinya (Mhadjir dalam Supeni dan Sari, 2011: 104).

Kemiskinan pada perempuan merupakan salah satu kondisi marjinalisasi yang jarang menjadi sorotan pemerintah ataupun lembaga - lembaga sosial. Hal ini dikarenakan definisi kemiskinan mengabaikan perempuan dan anak - anak pada standar kemiskinan itu sendiri. Misalnya saja sebagian orang menganggap istilah kemiskinan mengacu pada pengangguran, orang buta huruf, orang tunakisma atau tunawisma. Ada pula yang menilai orang miskin adalag yang tidak bisa mencukupi kehidupan keluarganya selama rentang waktu tertentu atau kemiskinan adalah kondisi seseorang yang memiliki rumah gubuk berdinding kayu, yang menderita gizi buruk dan tidak berpendidikan. Hal 
Musahwi, Pitriyani

inilah yang mengharuskan adanya pemberdayaan bagi perempuan khususnya dalam meluruskan asumsi mengenai peran ganda seorang istri.

Menurut Senada dan Kabeer (2001) dalam (Supeni dan Sari, 2011: 105) menyatakan bahwa terdapat lima usnusr utama yang perlu diperhatikan dalam proses pemberdayaan perempuan yaitu:

1) Kesejahteraan, terdapat tiga unsur penting perempuan dapa diakatakan sejahtera yaitu dari aspek ekonomi, aspek pendidikan dan aspek kesehatan

2) Akses, kemampuan perempuan untuk dapat memperoleh hak terhadap sumber daya produktif terutama dalam sektor publik.

3) Konsientisasi, pemahaman perbedaan peran jenis kelamin dan peran gender

4) Partisipasi, kesetaraan pasrtisipasi perempuan dalam membuat dan keputusan dan administrasi

5) Kesetaraan dalam kekuasaan terhadap faktor produksi dan distribu keuntungan

Lima unsur pemberdayaan perempuan di atas menjadi salah satu landasan berpikir pada penelitian dalam mengkaji mengenai peran perempuan dalam sudut gender. Unsur - unsur tersebut juga tercermin dari tujuan dan sistem kredit mikro Kopsyah BMI yang telah dibahas sebelumnya. Melalui produk pelayanan pinjaman tanpa agunan dan tabungan jangka panjang mencerminkan tujuan koperasi dalam memberdayakan perempuan agar dapat berperan dalam membantu perekonomian keluarga.

\section{Pemberdayaan Ekonomi melalui Pinjaman Khusus untuk Perempuan}

Menurut Dreze dan Sen dalam (Supeni dan Sari, 2011:101) kesejahteraan rumah tangga akan meningkat pada saat perempuan diberikan kebebasan dalam pendidikan, bekerja di luar rumah dan mempunyai pendapatan mandiri. Grammen Bank dan Kopsyah BMI memahami hal tersebut dimana sasaran dari setiap pembiayaan yang diberikan kepada masyarakat berfokus pada keluarga pra sejahtera melalui perempuan. Dengan demikian perempuan memegang peranan yang sangat penting dalam mentransfer pinjaman yang diberikan koperasi kepada keluarganya. Hal ini mengingat bahwa sistem koperasi meruapakan modifikasi dari sistem Grammen Bank yang 97\% nasabahnya adalah perempuan (Aini, 2019:35). Hal ini bukan tanpa alasan, Muhammad Yunus lewat Grammen Bank telah membuktikan bahwa ketika perempuan diberikan haknya memperoleh sumber daya produktif seperti kredit mikro mereka mampu meningkatkan pendapatan rumah tangganya dan memperluas cakrawala mereka yang didapat dari perkumpulan kelompok (Yusuf, 2008:73). 
Musahwi, Pitriyani

Adanya kredit mikro melalui simpan pinjaman tanpa agunan memberikan pengaruh yang besar terhadap masyarakat di Desa Girimukti khususnya para perempuan. Selain dapat mengurangi permasalahan ekonomi keluarga adanya bantuan tersebut mengaktifkan kreatifitas perempuan yang memanfaatkan dana tersebut dengan membuat usaha. Misalnya saja pada penelitian ini terdapat tiga informan yang merupakan para pelaku usaha perempuan yang dibantu oleh pinjaman dana dari koperasi.

Informan pertama adalah Ibu Emun, yaitu perempuan paruh baya berumur 66 tahun yang telah menjadi anggota Koperasi Syariah Benteng Mikro Indonesia selama 3 tahun. Semenjak suaminya meninggal pada tahun 2017 yang lalu mengharuskan informan menjadi tulang punggung keluarganya. Saat ini informan tinggal bersama anak keempatnya bersama tiga cucu yang masih sangat kecil. Selama lima tahun lebih informan menjadi pejual nasi uduk yang berada didepan rumahnya. Awal informan mengetahui informasi tentang kredit mikro Koperasi Syariah Benteng Mikro Indonesia ia dapatkan dari tetanggganya yang lebih dulu menjadi anggota koperasi. Sejak itu informan bergabung menjadi anggota koperasi dan menerima pinjaman untuk menambahakan modal usahanya. Selain itu, ia juga mengatakan bahwa dana pinjaman tersebut membantunya dalam kesulitan membayar tagihan listrik dan air pada saat itu.

"Atuh itu mah udah lumayan lama neng, Mak Emun mah pinjem ke koperasi itu dari tahun... 2018 an kalau enggak salah pokoknya udah 3 tahunan, awalnya mah pinjem buat nambahin modal warung (nasi uduk) terus ada sisa yaaa buat bayar ini itu ngasih Teh Yeyen (anaknya) sama anaknya .. itu juga awalnya mah denger dari orang katanya ada bantuan koperasi bisa minjemin uang.. atuh emak nyoba nanya - nanya sama si petugasnya itu... atuh alhdulillah sampe sekarang juga masih..." (Wawancara Informan Emun, 10 April 2021 pukul 09.33 WIB)

Berkat bantuan kredit mikro dari koperasi tersebut informan dapat mempertahankan usaha nasi uduknya yang sempat terhenti karena kekurangan modal. Penghasilannya pun meningkat sehingga dapat membantu memenuhi kebutuhannya sehari - hari anak dan cucunya.

Informan yang kedua adalah Ibu Ajah, yaitu seorang pedagang pecel yang berumur 36 tahun. Peran ganda yang dirasakan informan tersebut telah 10 tahun lalu lamanya. Saat itu informan melanjutkan usaha menjual pecel dari ibunya. Kondisi ekonomi keluarga juga menjadi faktor utama menjadikannya menjadi penjual pecel. Informan memiliki suami yang bekerja sebagai supir angkot yang penghasilan setiap harinya tidak menentu, sehingga informan pun harus membantu memberdayakan ekonomi keluarganya. Kini informan memiliki 3 orang anak yang masih sekolah dibangku SD, tentunya hal itu juga menjadi faktor lain informan bekerja. Aktifitas informan setiap 
Musahwi, Pitriyani

harinya dimulai dengan berjualan pecel pada pagi hari kemudian dilanjutkan pada sore hari berjualan gorengan dan ketoprak.

Kondisi ekonomi keluarga Ibu Ajah di atas menjadi alasannya mengikuti keanggotaan Koperasi Syariah Benteng Mikro Indonesia. Selama 2 tahun lebih informan telah menjadi anggota dan menerima bantuan pinjaman untuk membantu suaminya memenuhi kebutuhan ekonomi keluarga. Sama halnya dengan Ibu Emun, informan juga memanfaatkan dana pinjaman untuk menambahkan modal usaha pecel dan ketopraknya. Semenjak informan menjadi anggota koperasi dan menerima pinjaman, informan dapat mengembangkan usahanya yang awalnya hanya berjualan pecel pada pagi hari. Selain itu, informan juga mendapat arahan dari koperasi untuk dapat mengelola keuangan keluarganya untuk tabungan pendidikan bagi anak - anaknya.

"Ya alhamdulillah ya neng.. atuh semenjak minjem ke koperasi mah luamayan ngebantu teteh.. atuh pan teteh mah punya anak masih pada kecil terus bapaknya juga kan cuma nyupirin angkot jadi penghasilannya engga nentu, jadi ngebantu banget lah... ya iya sisanya buat nambahin modal jualan" (Wawancara Informan Ajah, 10 April 2021 pukul 15.29 WIB)

Kemudian informan ketiga adalah Ibu Acih, yaitu pedagang warung kopi berumur 43 tahun. Selain berjualan kopi dan mie instan informan juga bekerja sebagai buruh cuci. Informan memiliki 4 anak dan suami yang membantunya menjaga warung. Tempat atau rumah informan merupakan Rembug Pusat anggota Kopsyah BMI wilayah Kampung Bondol Desa Girimukti. Segala kegiatan tentang koperasi dilakukan di rumah informan, bahkan hampir seluruh anggota dalam wilayah tersebut menitipkan buku tabungannya pada informan. Berdasarkan penuturan informan kebutuhan ekonomi keluarganya hanya bergantung pada warung kopinya, sehingga informan pun memutuskan untuk menjadi anggota koperasi dan memanfaatkan pinjamannya untuk mempertahankan usahanya tersebut. Selama 3 tahun informan telah menjadi anggota koperasi, semenjak itu juga informan terbantu oleh bantuan kredit mikro yang diberikan koperasi.

"Yaa gimana neng kalau enggak minjem mah warungnya enggak kemodalan mana pengahasilannya dari situ - situnya kalau sampe tutup mah atuh dapet duit dari mana sehari - hari... yaa buat makan buat jajannya si Panji (anak informan)... belum lagi kan bayar listrik bayar kreditan dari mana kalau bukan dari warung mah.." (Wawancara Informan Acih, 11 April 2021 pukul 10.40 WIB)

Keberhasilan pemanfaatan kredit mikro yang dilakukan ketiga informan di atas merupakan bentuk pemberdayaan perempuan dari aspek kesejahteraan ekonomi dan akses dalam menerima sumber daya produktif seperti modal usaha. Bagi Lawang dalam 
Musahwi, Pitriyani

pengantarnya pada buku "Bank Kaum Miskin" milik Muhammad Yunus (2007) mengatakan bahwa kewirausahaan sosial seperti yang diterapkan oleh Grammen Bank seperti Kopsyah BMI telah berhasil membawa perubahan pada segala aspek pada masyarakat pra sejahtera khususnya kaum perempuan (Yusuf, 2008:67).

Kemampuan perempuan dalam meningkatkan perekonomian keluarga melalui pemanfaatan kredit mikro telah menjadi salah satu alat keluar dari lingkaran kemikinan. Sistem simpan pinjam milik Grammen Bank dan Kopsyah BMI menjadi senjata yang ampu dalam mencapai tujuan pembangunan dari lingkup kecil seperti keluarga. Kemiskinan yang terjadi diberbagi daerah di Indonesia bagi Yunus merupakan replikasi kapalsuan kapitalisme yang pada kenyataanya diskriminatif terhadap kaum miskin (khususnya perempuan) hal itu terlihat dari praktek perbankan yang hanya melilit mereka pada perputaran sistem bank yang rumit dan merugikan mulai dari bank lokal sampai bank internasional sekalipun. Selain itu, Yunus juga menambahkan bahwa kepalusuan humanisme juga yang terlihat manusiawi justru mengarah pada rasionalisasi atau logikalisasi pikiran yang sangat simplistik demi melayani atau menguntungkan kaum laki - laki (Yusuf, 2008:72).

\section{Pelatihan Mengatur Keuangan Keluarga Melalui Simpanan Wajib}

Seperti yang sudah dijelaskan sebelumnya bahwa Kopsyah BMI meajibkan anggotanya menabung setiap minggunya sebagai bentuk jaminan pada saat anggota tidak dapat membayar angsuran dan juga untuk mealtih anggotanya menyisihkan pendapatan keluarganya untuk hal - hal yang lebih penting. Sistem simpanan wajib yang dimaksud hampir mirip dengan sistem asuransi dimana anggota dapat meminjam tabungannya dalam konsisi yang darurat namun penarikannya dibatasi atau dengan kata lain koperasi dapat membekukan saldo tabungan mereka sampai akhir pelunasan.

Adanya simpanan wajib dan simpanan lainnya dapat mempengaruhi kondisi pendidikan, konsumsi dan kesehatan keluarga anggota koperai menjadi lebih baik dalam jangka panjang. Pada Grammen Bank sendiri memiliki tujuan tidak hanya membantu keluarga pra sejahtera dan kaum perempuan keluar dari kemiskinan namun juga mengubah struktur sosial dan ekonmi dimasyarakatnya. Kata 'wajib' dalam hal menabung seakan - akan menambah beban anggota koperasi, namun jumlah uang yang diwajibkan untung ditabung setiap minggunya tidaklah besar sehingga tujuan dari program ini adalah bukan saja menyisihkan sedekit uang mereka namun sebagai pembelajaran untuk mengehemat, menyimpan untuk kebutuhan di masa depan. Hal semacam ini dapat dikatakan sebagai proses pemberdayaan masyarakat. 
Musahwi, Pitriyani

Ketiga informan pada penelitian ini juga telah merasakan pemanfaatan dari simpanan wajib ini. Ibu Emun sejak menjadi anggota Kopsyah BMI tiga tahun lalu kini telah memiliki simpanan wajib sebesar Rp. 2. 406.000; sedangkan Ibu Ajah dengan kurun waktu selama dua tahun informan telah mempunyai simpanan wajib sebesar Rp. 1.844.000; kemudian Ibu Acih yang mempunyai simpanan wajib sebesar Rp. 2. 523.000; selama tiga tahun menjadi anggota. Jumlah simpanan wajib yang dimiliki anggota tidak hanya berasal dari anggota saja namun juga kalkulasi dari bonus yang diberikan koperasi setiap minggunya. Bonus tersebut diberikan sebagai bentuk penghargaan bagi anggota yang aktif membayar angsuran dan aktif mengikuti perkumpulan Rembug Pusat. Ketiga informan mengumpulkan simpanan tersebut terbilang dalam jumlah kecil setiap minggunya yaitu informan diwajibkan membayar simpanan wajib dibawah Rp. 15.000; per minggunya.

"Kaget puguh .. pas diliat enggak kerasa udh segitu aja padahal mah yah kita per minggunya juga paling nabung 10.000 doang tahu - tahu gede aja, lumayan aja neng, buat si Eneng entar sekolah atau buat di dede stunatan (Khitanan)... atuh itu mah dapet diambilnya juga entar kalau pinjemannya lunas baru bisa diambil" (Wawancara Informan Ajah, 10 April 2021 pukul 15.29 WIB)

Tidak hanya simpanan wajib Ibu Ajah pun menabung untuk kebutuhan pendidikan anak - anaknya dimasa depan, mulai dari Rp. 5000; informan menabung setiap minggunya dengan berharap tabungan tersebut dapat membantunya kelak. Kini simpanan pendidikan informan telah mencapai Rp.886.486; hasil kalkulasi penambagan bonus dari koperasi.

"Iya nabung itu (simpanan pendidikan) juga ... dikit - dikit juga lumayan neng dari pada abis buat jajan bae (aja), itu juga dikasih tahu sama petugasnya 'bu ibu kan punya anak masih kecil coba buat nabung buat sekolah' diomongin gitu sama petugasnya.. ih beneran neng" (Wawancara Informan Ajah, 10 April 2021 pukul 15.29 WIB)

Sejak adanya program simpan pinjam yang diberikan Kopsyah BMI berdampak pada peningkatan kemampuan perempuan dalam mengatur keuangan keluarga anggotanya. Menurut Rachamina (2009:14-15) pada umumnya perempuan lebih pandai menabung dibandikan dengan laki - laki. Hal ini diartikan bahwa perempuan memiliki potensi sangat besar dalam upaya penumpukan keungan dimasa depan. Perempuan juga sangat menjaga kepercayaan yang diberikan kepadanya saat ia diberikan kepercayaan mendapatkan aksesbilitas kredit dengan sebaik mungkin berusaha membayar, karena pada dasarnya sistem kredit adalah transaksi kepercayaan. 
Musahwi, Pitriyani

\section{Pelatihan Perempuan Disektor Publik Melalui Rembug Pusat}

Seperti yang telah dijelaskan sebelumnya bahwa mekanisme Kopsyah BMI yang mengadopsi sistem Grammen Bank ini memiliki mekanisme yang dimulai dengan keikut sertaan calon anggota dalam sebuah kelompok. Kelompok solidaritas ini berkumpul disuatu tempat yang disebut dengan Rembug Pusat. Perkumpulan di Rembug Pusat dapat mendorong para anggota koperasi untuk saling membantu satu sama lain. Calon anggota yang hendak meminjam pinjaman akan diwajibkan mengikuti kumpulan selama tujuh hari sebelum ditetapkan sebagai penerima pinjaman, hal ini dilakukan agar calon anggota dapat mempelajari kebijakan - kebijakan koperasi melalui pengujian lisan yang dilakukan pegawai koperasi. Aktifnya kehadiran anggota pada Rembug Pusat juga menjadi pengujian kepercayaan terhadap anggota dalam mengikuti segala aturan dan kebijakan koperasi.

Kegiatan yang dilakukan pada Rembug Pusat tidak hanya sosialisasi kebijakan kebijakan koperasi dan transaksi simpan pinjam saja namun juga melatih anggota menjadi orang yang disiplin. Bentuk kedisiplinan yang dimaksud adalah berupa pengarahan untuk duduk berbaris, membaca doa, sosialisasi pentingnya pendidikan, membayar infak dan mengucapkan ikrar anggota. Adapun ikrar anggota yang diucapkan terdiri dari 7 poin tujuan dari Kopsyah BMI.

1. Berusaha menambah rizki

2. Sanggup berpartisipasi aktif dalam permodalan Koperasi

3. Membantu anggota kumpulan dan Rembug Pusat apabila mereka dalam kesulitan

4. Menggunakan pembiayaan dari Kopsyah BMI untuk meningkatkan pendapatan keluarga

5. Mendorong anak - anak untuk bersekolah

6. Memiliki WC dan sumber air minum yang sehat

7. Hadir dan membayar kembali pembiayaan setiap minggu

Setelah ketujuh poin diatas telah diucapkan secara bersama - sama kemudian dilanjutkan dengan mengucapkan "Allah menjadi saksi atas apa yang kami ucapakan dan kami lakukan" sebagai bentuk kesungguhan anggota dalam menjalankan ikrar tersebut.

Menurut Saptandari (2000:290-291) kegiatan organisasi yang bergerak dibidang ekonomi seperti koperasi memiliki manfaat bagi perempuan sebagai langkah strategi dalam pemberdayaan perempuan. Bagi Saptandari setidaknya ada lima manfaat dari berbagai aspek yang dapat dirasakan perempuan ketika mengikuti organisasi atau perkumpulan seperti Rembug Pusat Kopsyah BMI. 


\section{Musahwi, Pitriyani}

1. Dari aspek ekonomi, manfaat yang dapat didapatkan anggota koperasi adalah dapat mengembangkan usaha, membantu ekonomi keluarga dalam memenuhi kebutuhan sehari - hari atau kebutuhan mendesak serta kemampuan mengatur kelancaran perputaran keuangan keluarga.

2. Dari aspek pendidikan, kegiatan dalam perkumpulan dapat meningkatkan pengetahuan dan ketrampilan anggota dalam berbagi hal mulai dari manajemen keuangan keluarga sampai kemampuan berorganisasi. Sedangkan pengetahuan, keterampilan dan pengalaman yang didapat adalah aksesbilitas untuk berwiraswasta dan mengembangkan diri.

3. Dari aspek sosial, perkumpulan akan membuka akses hubungan sosial yang luas, minimal dengan sesama anggota. Jaringan perkumpulan ini dapat dimanfaatkan untuk saling berbagi pengalaman, pengetahuan dan berbagai solusi pemecahan masalah keluarga antar anggota koperasi. Hal ini setidaknya akan memunculkan adanya kesadaran kolektif diantara kaum perempuan terhadap kemauan dan kemampuan untuk memperjuangkan hak-hak yang belum terpenuhi.

4. Dari segi psikologi, perkumpulan Rembug Pusat akan memberikan rasa percaya diri pada perempuan secara pribadi maupun kolektif. Akses dan keterlibatannya dalam pengambilan keputusan secara mantap, tanpa rasa bersalah dan percaya diri yang kuat dapat membongkar stereotype tentang sifat - sifat feminim yang diletakan pada perempuan selama ini.

5. Dari aspek politik, manfaat dari aspek ini dapat meningkatkan kesadaran bagi kaum perempuan untuk dapat mengambil keputusan dalam keluarganya. Kesadaran tersebut dapat diperoleh melalui pendidikan politik dasar dalam perkumpulan melalui kegiatan yang dilakukan.

\section{CONCLUSION}

Program kredit mikro Koperasi Syariah Benteng Mikro Indonesia atau Kopsyah BMI memiliki sistem yang diadopsi dari pola Grammen Bank, sehingga pengelolaan dan penerapannya sama. Produk - produk pembiayaan yang dberikan telah berhasil memberdayakan masyarakat pra sejahtera khususnya kaum perempuan seperti di Desa Girimukti Kecamatan Cimarga Kabupaten Lebak - Banten melalui simpan pinjam tanpa agunan. Adapun bentuk perbedayaan perempuan tersebut adalah sebagai berikut 
Musahwi, Pitriyani

1. Memberikan aksesbilitas kepada perempuan untuk memperoleh sumber dana berupa pinjaman tanpa agunan yang dapat digunakan untuk modal usaha dan membantu memnuhi kebutuhan ekonomi keluarga

2. Memberikan pelatihan mengelola keuangan kelurga melalui simpanan wajib dan simpanan sukarela yang dapat digunakan untuk kebutuhan mendesak dan kebutuhan dimasa yang akan datang seperti hari tua, pendidikan, umrah dan haji, qurban, sanitasi air dan listrik ataupun untuk hiburan

3. Memberikan ruang publik kepada perempuan melalui kegiatan Rembug Pusat dengan segala kegiatan yang mengarahkan kaum perempuan dapat terlibat dalam mengambil keputusan secara mandiri, menambah jaringan sosial, dan memperluas pengetahuan perempuan dari pengalaman para anggotanya.

\section{REFERENCES}

Aini, Bunga Nur. 2019. Pemberdayaan Ekononomi Masyarakat Miskin dengan Pola Grammen Bank (Studi Kasus di Koperasi Syrai'ah as-Sakinah Nganjuk). Ponorogo: IAIN Ponorogo.

Apriliani, Yosie. 2020. Strategi Penanganan Pembiayaan Bermasalah Tanpa Agunan Di Koperasi Syariah Benteng Mikro Indonesia Cabang Pembantu Curug Tangerang. Jakarta: UIN Syarif Hidayatullah

Budiman, Manneka. 2013. Bapak Rumah Tangga: Menciptakan Kesetaraan atau Membangun Mitos Baru?". Jurnal Perempuan Volume 18 No. 1, Edisi Maret 2013

Hartiningsih, Maria dkk. 2013. Agar Naik Kelas Menjadi Negara Kaya. Kompas.co.id diakses pada 16 April 2021

Irwan, Abdullah. 2001. Seks, Gender dan Reproduksi Kekuasaan. Yogyakarta: Tarawang Press

Putri, Rosseriayu M. Sjamsuddin, Sjamsir. Dan Nurani, Farida.2013. Pelaksanaan Pemberdayaan Perempuan dalam Mewujudkan Keadilan dan Kesetaraan Jender di Bidang Ekonomi pada Masyarakat Jombang (Studi Peran Badan Pemberdayaan Perempuan dan Keluarga Berencana Kabupaten Jombang). Malang: Universitas Brawijaya

Rachmina, Dewi. 2009. Fenomena Kesetaraan Gender dalam Kredit. Bogor: Intitut Pertanian Bogor (IPB)

Rahayu, Angger W. 2015. Perempuan dan Belenggu Peran Kultural. jurnalperempuan.org diakses pada 16 April 2021

Saptandari, Pinky. 2000. Pemetaan Kekuatan Organisasi Perempuan sebagai Upaya Pemberdayaan Perempuan dan Pranata Lokal. Makassar: Jurnal Antropologi Indonesia I

Satori, Djam'an dan Komariah, Aan. 2013. Metodologi Penelitian kualitatif. Bandung: Alfabeta

Supeni, Retno E. Dan Sari, Maheni I. 2011. Upaya Pemberdayaan Ekonomi Perempuan Melalui Pengembangan Manajemen Usaha Kecil (Studi Diskriptif Kegiatan Usaha Kecil Ibu - ibu Desa Wirolegi Kabuapaten Jember, Dampingan Pusat Studi Wanita UM Jember). Jember: Universitas Muhammadiyah Jember

Yusuf, Joni. 2008. Pemikiran Muhammad Yunus tentang Pengentasan Kemiskinan dalam Persepektif Hukum Islam. Surakarta: Universitas Muhammadiyah Surakarta

(Redaksi). 2019. Model Bisnis Kopsyah MBI untuk Wujudkan Pemerataan Ekonomi. Majalahpeluang.com. diakses pada 16 April 2021 